\title{
The Confucian View of World Order
}

\section{Frederick Tse-shyang Chen*}

In writing about the Confucian view of world order, I am not describing a religious perspective, at least in a traditional Western sense. Confucianism is not.a religion, although it is sometimes mistaken for one. ${ }^{1}$ At one time Confucianism was sought to be constitutionally declared the state religion of the new republican China. ${ }^{2}$ More correctly, however, Confucianism is a body of philosophical teachings about human beings, their values, their institutions, and so on or about, simply, a way of life in this, but not the next, world.

China does not have an indigenous religion. What is commonly known as the "three religions" is probably more correctly known as the three "teachings." The three are Buddhism, Taoism, and Confucianism. Of these only Buddhism is a religion, but it was introduced from abroad. Taoism refers both to the philosophies of some Chinese scholars and to certain practices including alchemy in the search of elixir vitae, hygienic breathing and meditation, faith-healing ${ }^{4}$, and magic. ${ }^{5}$

- Professor of Law, University of Bridgeport. The author gratefully acknowledges that he has drawn on basic research previously done under a grant from the Pacific Cultural Foundation. This article in its original form, will be published in THE Influence of Religion on the Development of International Law, ed. Mark W. Janis to be published in the Netherlands by Martinus Nijhnoff Publishers in 1991. (ISBN 0-7923-0934-1).

1. See H. A. Giles, Confucianism and Its Rrvals (1915); W. E. Soothill, Three Religions of China (1929).

2. Liu Wu-chi, A Short History of Confucian Philosophy 184 (1964); Y. C. Hsieh, On the Constitution of the Republic of China 53 (7th ed. 1956) (In Chinese).

3. In Chinese, chiao means "teaching" and tsung-chiao (or its shorthand chiao) means religion. Thus, the term "three chiao" literally can mean either three religions or three (bodies of) teachings. It is better to take the term by the latter meaning since a religion is also a body of teaching, whereas not every body of teaching is a religion. See, W.E. Soothill, Three Religions of China 14-15 (1923).

For a brief history of the three chioo, see T. S. Huang, A General History of China, v.1, 284-86 (1983) (In Chinese).

4. For an excellent summary of Taoist philosophy, see generally H. C. Creel, Chinese Thought: From Conffucius to Mao Tse-tung 94-114 (1953).

5. See E. O. Reischauer \& J. K. Fairbank, East Asta, The Great Tradition $137-41$ (1960). 
It acquired the character of an organized religion not because of any domestic Chinese development but through the influence of Buddhism. ${ }^{6}$ Confucianism does not share a number of the essential characteristics of a religion.' It does not advocate a belief in a deity, nor does it have an accepted doctrine of salvation, nor does it use sacred stories to aid propagation. While it does employ rituals and have a "code of conduct," the attendant perspectives are non-religious in character.

Though Confucianism is not a religion; it has had a unique place in the culture of mankind. For more than two thousand years Confucianism was the most prominent force in shaping the culture of the world's most populous nation, a nation which does not have a native religion of its own. Books on international law or order usually do not include any substantial discussion of Confucius or Confucianism, but the Confucians do have a view on world order. This view ought to be compared to the world's religious and other perspectives. In the following pages, I propose to explore it under these headings: (1) Postulation of Goal; (2) Confucian Conception of Community: World as "Tien-Hsia"; (3) Confucian Conception of Order: Non-Differentiation of Legal and Moral Order; (4) Minimum Order; and (5) Maximum Order.

\section{Postulation of Goal}

The Confucians postulate for world order the goal of ping. Ping denotes peace, harmony, evenness, equality, fairness, and the like. A world that has achieved ping is a world in which the Great Way ${ }^{8}$ has prevailed, and such a world is known as a world of Great Harmony. As portrayed by Confucius:

When the Great Way prevailed, the world community was equally shared by all. The worthy and able were chosen as office-holders. Mutual confidence was fostered and good neighborliness cultivated. Therefore people did not regard as parents only their own parents, nor did they treat as children only

6. Id. at 140 .

7. For "Chief Characteristics of Religion," see, World BooK Encyclopedia, v. $16,207-10$ (1982).

8. For illuminating works on basic Confucianism see H. G. CReEL, Confucius and the Ghinese Way (1949); T. C. Chen, The Theory of Confucius (4th ed. 1969). For a non-traditional current mainland-Chinese perspective, see S. S. TSAl, Systems of Confucian Thinking (1982) (in Chinese); Confucius (S. C. Wang ed. 1985) (in Chinese); Kuang Yaming, A Critical Blography of Confucius (1985) (in Chinese). 
their own children. Provision was made for the aged till their death, the adult were given employment, and the young enabled to grow up. Old widows and widowers, the orphaned, the old and childless, as well as the sick and the disabled were all well taken care of. Men had their proper roles and women their homes. While they hated to see wealth lying about on the ground, they did not necessarily keep it for their own use. While they hated not to exert their effort, they did not necessarily devote it to their own ends. Thus evil schemings ceased to appear, and robbers, thieves and other lawless elements failed to arise, so that outer doors did not have to be shut. This was a world of Great Harmony. ${ }^{9}$

All Confucian teaching may be regarded as aimed at the achievement of this ultimate goal of a world characterized by ping. The Book of Great Learning, regarded as the "gate by which first learners enter into virtue," 10 propounded eight virtuous accomplishments that every individual is urged to attempt. These are: (1) investigation of things; (2) extension of knowledge; (3) sincerity of thoughts; (4) rectification of the heart; (5) cultivation of the person; (6) regulation of the family; (7) government of the state; and (8) ping of the world. These eight items so systematically categorize Confucianism that all Confucian teaching can be grouped under them." The eight are meant to be accomplishable and accomplished in succession. Each one is prerequisite to and preparatory for the next. The completion of the first seven must therefore precede that of the eighth. Thus, the accomplishment of the

9. L. F. Chen, The Confucian Way: A New \& Systematic Study of The "Four Books"' 577 (1972) (Quoting LI CHI, LI YUN). (I have made a minor change to the translation to reflect my understanding.)

10. These are the words of the philosopher Cheng as they appear in the Introductory Note to virtually every version of the Chinese text of Great Leaming. Great Learning is one of the "Four Books," or the "Books of the Fours Masters." The four refers to The Great Learning, The Doctrine of the Mean, The Confucian Analects, and The Works of Mencius. In this essay I shall rely principally on the Four Books for my authority and on the Tso's Commentary to Spring and Autumn for the supply of cases. There is virtually no doubt as to the genuine authorship of all these works. I do not intend, nor am I competent, to get embroiled in quarrels about authorship of the Chinese classics. In this essay, all quoted passages from the Four Books and from Tso's Commentay are taken from the translation of James Legge, the renowned British scholar. His translation of all five works appears in J. Legge (tr.), The Chinese Classics in 5 vols. I have made changes to $\mathrm{Mr}$. Legge's translation to reflect my understanding. Great LEARNING is in Vol. I.

11. L. F. CkeN, supra note 10 (reorganizes the "Four Books"). 
eighth would mean that all of the Confucian teachings would have been carried out. ${ }^{12}$

From the meanings of ping and the above portrait of the ideal world, it may be seen that two central themes characterize ping: minimum order, in the sense of peace and tranquility; and maximum order, in the sense of abundance, sharing and general contentedness. A world that has reached the stage of ping is aptly called a "peaceful and happy world." 13

\section{Confucian Conception of Community: World as "Tien-Hsia"}

I have been using the word "world" to describe the community for which the Confucians postulate the goal of peace and happiness. The original Confucian text described that community by using the Chinese words tien-hsia, literally, "all under Heaven (or the sky)." This term can be narrowly or broadly interpreted. Since all under Heaven at the time of Confucius was supposed to be ruled by the Son of Heaven, the king of China, tien-hsia naturally refers to that kingdom in China known as Eastern Chou. Thus, some translators of Confucian classics correctly rendered tien-hsia into the English word "kingdom." Tien-hsia also admits a broader meaning. Since all under Heaven is extensive enough to comprehend the entire world, or the entire known world, the term can cover a community larger than the Chinese kingdom. ${ }^{15}$ This means that today, the term can refer to the entire global community of mankind or even the still larger earth-space community. In this essay I will take the term in its broader meaning. Such a use may be justified on grounds other than linguistic permissibleness. First, there are major similarities between the tien-hsia of Confucius' time and that of the present time. What was postulated for one may be meaningful

12. According to Great Leaming: "The ancients who wished to illustrate illustrious virtue throughout the kingdom, first ordered well their own States. To order well their States, they first regulated their families. To regulate their families, they first cultivated their persons. To cultivate their persons, they first rectified their hearts. To rectify their hearts, they first sought to be sincere in their thoughts. To be sincere in their thoughts, they first extended to the utmost their knowledge. Such extension of knowledge lay in the investigation of things." Great Leaming, Text of Confucius, 4.

13. Legge uses both "tranquil and happy" (op. cit., Great Lrarning supra note 11, at 359) and "peaceful and happy" (Id. at 373).

14. Both Liu and Legge translate tien-hsia into "kingdom" or sometimes "empire."

15. The author of Chen, supra note 10, adopts the broader meaning but the translator uses the narrower meaning in rendering the original text of the classics into English. 
and similarly appropriate for the other. Second, given the cosmopolitan and realistic perspective of Confucius, the broader reading is probably the more apposite. Third, in Confucius' time, as in the present, no state can secure order unless all other states can also achieve order. A peaceful and happy China cannot last unless the rest of the world under Heaven also enjoys peace and happiness.

Confucius lived in the so-called "Spring and Autumn" period (722-481 B.C.) in Chinese history. This was a wicked period. As described by Mencius, the number-two sage for the Confucians, "The world was fallen into decay, and right principles had dwindled away. Perverse discourse and oppressive deeds were again waxen rife. Cases were occurring of ministers who murdered their rulers, and of sons who murdered their fathers." 16 At the time, the king of Eastern Chou was ruler of the Chinese kingdom in name only. ${ }^{17}$ His vassal states all became "fragments of a disintegrated empire," 18 and each fragment stood, for all practical purposes, as an independent sovereign vis-a-vis Eastern Chou. These states fought among themselves and with the barbarian states and tribes on the peripheries of China. Might prevailed over right, and hegemons emerged as many weaker states were swallowed up. ${ }^{19}$ In Confucian classics, tien-hsia was, intended to refer to this disintegrated kingdom of Eastern Chou, but the inter-state community of Eastern Chou was in many important respects similar to the international community of the present day. The vassal states were all independent sovereign states much like the sovereign nation-states of today. The larger inter-state community then was decentralized as is the international community of the present day. Even the hegemony politics shared similarities with the modern super-power politics. Although there was in existence a king who could be looked upon as representing some sort of a "world government," that government was more illusory than real.

The Confucians have always held a cosmopolitan outlook and a realistic view of the larger community. It is this cosmopolitanism and realism that warrant one also in thinking that the Confucians would, approve of the broader interpretation of the term tien-hsia. Confucius himself supplied a "living" example of this interpretation. Born a subject of the State of $\mathrm{Lu}$, he spent many years travelling abroad in

16. Works of Mencius, Bk. III, Pt. II, Ch. IX.

17. D. J. Li, The Ageless Chinese: A History 45 (1965).

18. Britron, Chinese Interstale Intercourse Before 700 B.C., 29 AM. J. INT'L L. 616, 618 (1935).

19. D. J. Li, supra note 18 , at 50 . 
search of opportunities for public service..$^{20} \mathrm{He}$ realized that his goal of a peaceful and happy world could not be realized without the support of those who, wielded effective power, as distinguished from the pretended authority held by the Eastern Chou king. Effective power was, in the hands of the rulers of the Chinese and barbarian states and tribes.

Through holding public offices in one of those states, he would get the opportunity to implement the Way and to influence the thoughts and heart of a ruler. ${ }^{21}$ It was through the proper government of that state that he might have a realistic chance of achieving the peaceful and happy world that he had in mind. Confucius not only went to a number of Chinese states, but at one time also contemplated going to where the "nine wild tribes of the east" resided. When someone warned him that the tribespeople might be a bit crude for him, he retorted, "If a virtuous man dwelt among them, what crudity would there be?" 22 If his search among the Chinese states had been fruitful, he would have undoubtedly sought to implement the "nine standard rules" for the government of tien-ksia and of a state in the state of his employment, as enunciated in the book on The Doctrine of the Mean. ${ }^{23}$ The nine standards included the standard of "indulgent treatment of people from a distance." To Confucius, "people" would include the barbarians. One way to have a peaceful and happy world is to have all the states of the world well-governed. The other is by a well-governed state's winning over all the peoples of the world. Mencius was particularly explicit on this second way of seeing the Great Way prevail in the

20. Both Confucius and Mencius were eager to hold public offices so that they could implement their ideals. Confuctan Analects, Bk. VII, Ch. X; Bk. IX, Ch. XII; Works of Mencius, Bk. III, Pt. II, Ch. III; Bk. II, Pt. II, Ch. XII.

21. Professor M. S. McDougal made this point: "The effective key to the improvement of global constitutive process and public order decision, to insuring that some of the many equivalent options for improvement are in fact put into practice, is of course to be found in the management of the global process of effective power, that is, through modification of the perspectives of the elite who maintain that process." McDougal, Intemational Law and the Future, 50 Mrss. L. J. 259, 332 (1979).

22. Confuclan Anslects, Bk. IX, Ch. XIII.

23. "All who have the government of the kingdom or of a State to attend to have nine standard rules to follow: Cultivation of the person; honoring of worthy people; affection towards relatives; respect towards the great ministers; kind and considerate treatment of the whole body of officials; dealing with the mass of the people as children; encouraging the resort of all classes of artisans; indulgent treatment of people from a distance; and the kindly cherishing of the princes of the States." Doctrine of the MEAN, Ch. XX in Chen, supra note 10 , at 413 . 
universe in his advice to the rulers of his day. ${ }^{24}$ Further, one of the "righteous rules" of Confucianism that may be derived from the book of Spring and Autumn ${ }^{25}$ is to treat the barbarians as Chinese if they followed the Chinese rules of conduct (" $l i$ ") and to treat the Chinese as barbarians if they followed the barbarian rules of conduct. ${ }^{26}$

Moreover, the restrictive reading of tien-hsia would make sense only in a first reading of the classical text. After the tien-hsia in the narrow sense was to coin a word, pinged, the cohesive kingdom of China would then be reduced to a mere state vis-a-vis the rest of the larger world. This larger world, though decentralized, would next have to be pinged. With the unification of China in 221 B.C., China has, in reality, been a single unit of the larger community; a state in the decentralized world. It thus makes sense to give tien-hsia in the Confucian text the broader reading.

Confucius explained his extensive foreign travels in search of office in terms of "association with mankind." 27 The faithful Confucians are all supposed to be deeply engaged in the "adjustment of the great invariable relations of mankind and the establishment of the great fundamental virtues of humanity." 28 They are supposed to "treat all China as one person and all under Heaven as one family." 29 It would

24. For an example of Mencius' advice to King Hwei of State Liang and his advice to King Hsuan of State Chi, see Works of Mencius, Bk. I, Pt. I, Ch. III; Bk. I, Ch. VII. It should be noted that this is not imperialism, as the peoples who would "come" from other states would be doing it by their own volition and desire.

25. A word about Spring and Autumn, maybe in order. The work, in form a chronicle of important events during Spring and Autumn, has always had a place of special importance in Confucianism. It was authored by Confucius not only to record historical events, but also to pass judgment upon the actors involved. This latter function was performed through discriminatory use of words that subtly imply "praise or censure." The work is accompanied by three commentaries that supply details and offer interpretations. Many of the cases referred to in this essay are taken from one of these commentaries, the $T$ so's Commentary. The reader is supposed to draw from Spring and Autumn the so-called "righteous decisions of Spring and Autumn" and perceive the norms or principles implicit therein. The Ch'Un Ts'ew (Sprung and Autumn) with the Tso Chuen (Tso's Commentary) appears in The Chinese Classics vol. V (Legge trans. 1960). It should be noted that the decisions and norms thus drawn have been used as basis for deciding actual cases. See T. CH'v, LAW AND Society in Traditional Ghina 276 (1961).

26. M. Chien, An Outline of National History, v. 1, 38 (In Chinese).

27. Confuclan Analects, Bk. XVIII, Ch. VI.

28. Doctrine of the Mran, Ch. XXXII, in The Ghinese Classics, vol. I, 429 (Legge trans. 1960).

29. I have lost the source from which I took these remarks. But Confucian Analects 
be hard to believe that in this ever-shrinking world of the present day, the Confucians would eschew any part of the global community in their effort at securing the "illustration of the illustrious virtue all under Heaven." 30

Confucius not only identified with the larger community and appreciated the distinction between the effective power and the formal authority that operate in society, but he also regarded the individual human being as the ultimate actor in all community processes. ${ }^{31}$ It is in the individual, and not the nation-states, that the Confucians would find the starting point and locate the responsibility for building world order. Individuals identify with groups, the more important of which the Confucians list as the family, the state, and the world community. ${ }^{32}$ The Confucians plan to reach their ideal world through the perfection of the individuals and their groups. Each person must first seek the perfection of himself and then broaden his efforts to bring about the perfection of the groups with which he identifies and through which he acts. ${ }^{33}$

Earlier, I listed the eight virtuous tasks or accomplishments of Great Learning. Of those eight, the first five pertain to the perfection of the self and the last three are examples of the perfection of groups. I pointed out that the eight tasks are supposed to be pursued in the order in which they were listed. The Confucians are particular about not confusing the "root" with the "branches" of things or the "beginning" with the "end" of affairs. ${ }^{34}$ Since ordering the individual is like the root or the beginning for ordering the world, the importance of self-perfection cannot be overemphasized. It must be required of

contains this advice given by one of Confucius" disciples to another: "Let the superior man never fail reverentially to order his own conduct, and let him be respectful to others and observant of propriety:-then all within the four seas will be his brothers. What has the superior man to do with being distressed because he has no brothers?" Confucian Analects, Bk. XII, Ch. V.

30. Great Learning, Text of Confucious, 1: "What the Great Learning teaches, is-to illustrate illustrious virtue; to renovate people; and to rest in the highest excellence."

31. For a realistic and comprehensive modern view, see McDougal, Lasswell. And Reisman, Theories About International Law: Prologue to a Configurative Jurisprudence, 8 VA. J. INT'L L. 188, 200-02 (1968).

32. See text following note 10 .

33. Doctrine of The MEAN, Ch. XXV: "The possessor of sincerity does not merely accomplish the self-perfection of himself. With this quality he perfects others and other things also."

34. Great Learning, Text of Confucious, 3: "Things have their root and their branches. Affairs have their end and their beginning. To know what is first and what is last is to be near the Way." 
everyone, including even the king. Thus, as summarized in Great Learning.

Things investigated, knowledge became complete; knowledge complete, thoughts were sincere; thoughts sincere, hearts were rectified; hearts rectified, persons were cultivated; persons cultivated, families were regulated; families regulated, States were rightly governed; States rightly governed, the whole world (tien-hsia) was made tranquil and happy. From the Son of Heaven to the masses of the people, all must consider the cultivation of the person the root of everything besides. It cannot be, when the root is neglected, that what should spring from it will be well ordered. ${ }^{35}$

Confucian Conception of Order: Non-Differentiation of Legal and Moral Order

There is much misunderstanding regarding the legal tradition of China. This is due in part to the fact that Western knowledge about China is not great, and to the lack of calibration of fundamental concepts. For example, the author of a popular textbook on jurispradence wrote:

The Chinese have never had a legal tradition at least as that term is understood in the West. Legality has no roots in Ghinese civilization, law being regarded as the sign of an imperfect society. Confucius, the fount of traditional Chinese wisdom, believed that societal cohesion was furthered by example and established morality, not by regulation and punishment. A distinction was drawn in Chinese culture between $L i$ and $F a: F a$, law, is an unpleasant necessity; $L i$, an ethical system of proper behavior is the more worthy and more useful method of social control. ${ }^{36}$

First, the basic assertion in the first two sentences is misleading. The writer fails to make clear what he means by "legal tradition" and "law," nor does he indicate whose understanding in the West he has

35. Id at 5-7.

36. LoRd Lloyd of Hampstead, Introduction to Jurisprudence 760-61 (4th ed. 1979). Compare Schwartz, On Attitudes Toward Law in China, in M. Katz, Government Under Law and the Individual 27 (1957); S. P. Sinha, What Is Law 40 et seq. (1989); Lord Lloyd of Hampstead and M. D. A. Freeman, Lloyd's INTRODUCTION TO JURISPRUDENGE (5th ed. 1985) only briefly mentioned $l i$ and $f a$ in note 41 at 1101 . 
in mind. The West does not have a uniform understanding of law or legal tradition. The writer's own textbook attests to this fact. The major schools of jurisprudence in the West clearly have different conceptions of law among themselves. Each appears to be inadequate in some important respects. ${ }^{37}$ If "positive law" (formally enacted and published as such) is what the writer has in mind by law, then China would appear to have a long and rich legal tradition. Tso's Commentary to Spring and Autumn reported the casting as early as 536 B.C. of tripods in the State of Cheng with crimes and their punishments described on them..$^{38}$ There is also, accumulated over two millennia, an overabundance of codes, statutes, ordinances, edicts and other written laws and orders governing criminal, administrative and other matters; not to mention the ever-present binding customs. ${ }^{39}$ In fact, the written law formed the staple of $f a$. Even in inter-state relations, one can note the many "covenants" that were concluded (and readily breached, of course) as early as the time of Spring and Autumn.40

Second, as to the distinction between $l i$ and $f a$, it should be pointed out that the English word "law" is not the equivalent of the Chinese word $f a$. When $f a$ is used as dichotomous with $l i$, it customarily means "criminal law" only. The English word "law" certainly means more than just criminal law. It should also be pointed out that the Chinese word $l i$ does not refer merely to "ethical" rules of proper behavior. $L i$ includes rules governing constitutional, administrative, inter-state and civil matters as well as moral propriety." Under the maxim "to depart from the province of $l i$ is to enter the province of punishment (hsing)," li obviously is law that is enforced even through criminal sanctions. A passage from the book of $\mathrm{Li} C h i$ will indicate the broad scope of li's coverage:

37. MaDougal, Lasswell and Reisman, supto note 32.

38. Note, supra note 26 at 609-10.

39. Some of the familiar treatises on Chinese legal history are: K. Y. CHEN, History of Chinese Legal Institutions (5th ed. 1973); T. L. Hsu, A Brief History of Chinese Legal Institutions (4th ed. 1967); H. L. Yang, History of Chinese Legal Thinking (4th ed. 1978); Y. Y. Lin, History of Chinese Legal Institutions (rev. 7th ed. 1980); Y. H. TAI, Chinese Legal History (2d ed. 1969); A Collection of Papers on History of Chinese Legal Institutions (K.S. Hsieh and L.C. Cha eds. 1968). All of these works are in Chinese. T. CH'v, supra note 26, and Bodde and Morris, Law in Imperial China (1967) are useful volumes in English.

40. For a couple of examples, see infra pp. 68-9.

41. See K. Y. Chen, A Discussion and Reappraisal of Chinese legal INstitutions and Their Formation and Development from the Perspective of Chinese Culture, in K. S. Hsieh and L. C. Cha, supra note 40 at 1. 
They are rules of $l i$, that furnish the means of determining (the observances towards) relatives, as near and remote; of settling points which may cause suspicion or doubt; of distinguishing where there should be agreement, and where difference; and of making clear what is right and what is wrong. ... The course (of duty), virtue, benevolence, and righteousness cannot be fully carried out without the rules of $l i$; nor are training and oral lessons for the rectification of manners complete; nor can the clearing up of quarrels and discriminating in disputes be accomplished; nor can (the duties between) ruler and minister, high and low, father and son, elder brother and younger, be determined; nor can students for office and (other) learners, in serving their masters, have an attachment for them; nor can majesty and dignity be shown in assigning the different places at court, in the government of the armies, and in discharging the duties of office so as to secure the operation of the laws; nor can there be the (proper) sincerity and gravity in presenting the offerings to spiritual beings on occasions of supplication, thanksgiving, and the various sacrifices. ${ }^{42}$

The broad and sweeping coverage of $l i$ hardly shows that it is or is intended to be, merely moral in nature.

It is clear that the Western concept of law is not coextensive with the Chinese concept of $f a$, and that the Chinese concept of $l i$ is not merely ethical or moral. If we must find some comparable Western expression for li, I think the late Professor Po-chi Wang has probably found a good one. ${ }^{43}$ Professor Wang thought that Leon Duguit's "social norm" is the conceptual equivalent of $l i$. In Duguit's conception, that part of the social norm is law which is supported by socially organized reaction against its violation. This part is referred to as the "juridical norm." $L i$, as we have seen, is in part also enforced by socially organized reaction. Following this $l i$ comprehends both law and morals, and $f a$ is law but not all law is fa.

Professor Wang's analogy throws much light on a vexing problem. But, when thinking of law, even his focus seems to be confined to

42. The $\mathrm{Li}_{\mathrm{Chi}}$, Chu Li, Pt. I, in The Sagred Books of China: The Texts of Confucianism vol. XXVII, 63-64 (Legge trans. 1960).

43. P. C. Wanc, Modern Western Legal Thinking and Chinese Traditional Culture el seq. (1956) (In Chinese). For Duguit's theory, see Dugurt, Objective Law, 20 Col. L. Rev. 817 (1920) and 21 Col. L. Rev. 17 (1921). 
"rules," with its attendant shortcomings of overemphasizing "perspectives" and "authority" to the neglect of "operations" and "control." A more balanced analysis would have to take into account all of these elements. The questions of operation and control are matters of empirical inquiry. It should be pointed out that by combining the vast stores of $f a$ and that portion of $l i$ which were actually applied and attended by effective control, one would find an incredibly rich "legal tradition" in China sufficient to satisfy the most curious intellect. For present purposes it suffices to note that since $l i$ is both legal and moral in its nature, the social order that is secured by means of $l i$ is at once legal and moral. In the Confucian conception the order of a community is also at once legal and moral so long as that order is secured by $l i$. There is no differentiation between legal and moral order. The implementation of $l i$ will obviously have to rely both on sanctions familiar to law and on other techniques including example. Confucius may have preferred example to punishment and morality to law, but he never said that law and punishment have no place in society. In fact, he said, "In hearing litigation, I am like any other person." 45 Mencius mentioned litigants going to the sage Shun for the resolution of their disputes. ${ }^{46}$

The whole story of "Confucianization of law" is a facinating record of the efforts of Confucians at combining authority and control to produce law. ${ }^{47}$

\section{Minimum Order}

The Confucian conception of minimum order has three core ideas: (1) absence of unauthorized coercion or violence; (2) disappearance of litigation; and (3) authorized uses of force.

\section{Absence of Unauthorized Coercion or Violence}

In inter-state relations, the Confucians have condemned the unauthorized use of force. ${ }^{48}$ Spring and Autumn was a period of wars in

44. For elaboration of these terms, see McDougal, Lasswell and Reisman, supra note 32, 202-03.

45. Great Learning, Commentary, Ch. 4; Confucian Analects, Bk. XII, Ch. XIII.

46. Works of Mencius, Bk. V, Pt. I, Ch. V.

47. For the story, see Ch'u supra note 26 at 267 et seq.

48. Mencius, who lived during the so-called "Warring States" period condemned those as "great criminals" who boasted about and marketed their skills at marshalling troops and conducting battles. Works of Mencius, Bk. VII, Pt. II, Ch. IV. 
which the Chou king fought with barbarian or Chinese states or tribes, and the Chinese states fought among themselves or with barbarians. ${ }^{49}$ The causes for war were many, but one study that covered 1,001 wars during a mere span of nine years, reported six: insult to diplomatic agents, failure or refusal to attend a convention for drawing up a treaty, violation of a treaty, desire for leadership and preeminence, avenging a previous defeat, and desire for conquest. ${ }^{50}$ Mencius once concluded, "In the Spring and Autumn there are no righteous wars. Instances indeed there are of one war better than another [but all are equally unauthorized]." 51 An example of a "better" war is the war at Chaolin in 655 B.C. in which the invaded state Chu submitted without the effusion of blood. On that occasion, Chi and its allies sought to justify their invasion of Chu on the strange grounds of exacting an account for Chu's failure to render tribute to the nominal Chou king and of making an inquiry into the unexplained drowning three centuries ago of King Chao of Chi. ${ }^{52}$ These claimed justifications were hardly sufficient to purge the invasion of its unauthorized character, but the war was regarded as better because no life was lost in it.

\section{Disappearance of Litigation}

In jurisprudential thinking, there is minimum order so long as disputes are resolved. by recourse to an appropriate decision-maker rather than by violence or threats of violence. Under that thinking, disputes and litigation still exist in society. The Confucian ideal of a peaceful and happy world aims for more. It calls for the disappearance of litigation, not merely the orderly conduct thereof. How is this possible? The answer is by making known virtue throughout the world and by the universal observance of the Way. A self-perfected person knows the difference between right and wrong. If his claim is spurious or questionable, he will feel too ashamed to raise it. He will also feel ashamed not to render his opponent what is rightly the latter's due. ${ }^{53}$ As Confucius put it, "If the people be led by laws, and uniformity is sought to be given them by punishment, they will try to avoid the punishment, but have no sense of shame. If they be led by virtue, and

49. Ch'enc, Intemational Law in Early China (1122-249 B.C.), 11 Chinese Soc. \& Pol. Sci. Rev. 38, 251, 262-63 (1927).

50. Id. at 260-61.

51. Works of Mencius, Bk. VII, Pt. II, Ch. II.

52. Ch'UN Ts'ew at 140-41.

53. Great Learning, Commentary, Ch. IV. 
uniformity is sought to be given them by the rules of $l i$, they will have the sense of shame, and moreover will become good."54 Thus, while Confucius felt confident that he could try lawsuits as well as anyone else, he still held the preference that "What is necessary is to cause the people not to litigate." 55

\section{Authorized Uses of Force}

Certain uses of force are regarded as appropriate and perhaps as in the interest of minimum order. These include: self-defense, humanitarian intervention, punitive expeditions, and the "right" to revolution.

\section{Self-Defense}

The Confucians would permit the use of force for self-defense, both individual and collective. In The Works of Mencius we find an opinion rendered by Mencius. Teng, a small state, was situated between two large and powerful neighbors, Chi and Chu. Teng's ruler, who was concerned about national security and survival, consulted Mencius as to what course to follow. Mencius, well aware that neither Chi nor Ghu was inclined to follow $l i$, rendered a reply which showed approval to individual self-defense:

Your plan is beyond me. If I must counsel you, I can only suggest one thing. Dig deeper your moats, build higher your walls, and guard them with your people. In case of attack, be prepared to die in your defense, and have the people so that they will not leave you. This is a proper course. ${ }^{56}$

Another case of self-defense involved the defeat of $\mathrm{Ch}^{\prime}$ in by Chin, during a war between $\mathrm{Ch}^{\prime}$ 'in and Cheng, when Chin felt the presence of "imminent danger." '57

The collective security enterprises led by the hegemonic ruler of Chi, Duke Hwan, during Spring and Autumn met with the approval of Confucius. With the loss of control by the Chou King, the vassal states could no longer depend on Chou for the maintenance of order. Now they had to fend for themselves. In the face of an expansionist $\mathrm{Chu}$ in the south and increasing barbarian invasions from the north,

54. Confucian Analects, Bk. II, Ch. III.

55. Op. cit., supra n. 53.

56. Works of Mencius, Bk. I, Pt. II, Ch. XIII. See also id., Bk. I, Pt. II, Ch. XIV.

57. Ch'ENG, supra note 50 , at 44 . 
the survival of many Chinese states hanged by a thread. Duke Hwan, aided by his able prime minister, Kwan Chung, summoned these states to many conferences, organized them, and became the acknowledged hegemon. Under Duke Hwan's leadership the allied states were successful in turning back and keeping the encroaching northern barbarians to the north of the Yellow River, thus perpetuating the existence of the states of Yen, Hing, Wei and their own. By a combined invasion, the allies were able to exact a covenant from the southern state of Chu. Confucius remarked: "The Duke Hwan assembled the rulers of states together, and that not with weapons of war and chariots. It was all through the influence of Kwan Chung. Whose benevolence was like his?" Whose benevolence was like his? ${ }^{58}$ Again, said the Master:

Kwan Chung acted as prime minister to the Duke Hwan, made him leader of all the princes, and united and rectified all under the sky. Down to the present day, the people enjoyed the gifts he conferred. But for Kwan Chung, we should now be wearing our hair unbound and the lappets of our coats buttoned on the left side [like the barbarians do]. ${ }^{59}$

Confucius appraised Duke Hwans, "Upright and not crafty."

\section{Humanitarian Intervention}

The Confucians would approve the use of force by one state against another state for the protection of human rights in the latter if properly carried out. The case of Chi and Yen is interesting. Chi and Yen both were large states, each being a "country of ten thousand chariots." The ruler of Yen was tyrannical. His people lived in the intolerable conditions of "hot fire and deep water." When Chi went to the relief of the Yen people by military force, it took no more than fifty days to complete the conquest. After the conquest; however, the ruler of Chi also behaved tyranically to the Yen people, "having slain their fathers and elder brothers, put their sons and younger brothers in confinement, and pulled down the State Ancestral Temple and begun to appropriate the precious vessels therein." He also annexed Yen. Whereupon, the rulers of various states deliberated together about aiding Yen and delivering it from Chi's abusive power. Mencius first discussed the annexation question. His view was that if the people of Yen would

58. Confuctan Analects, Bk. XIV, Ch. XVII.

59. Id., Bk. XIV, Ch. XVIII.

60. Id., Bk. XIV, Ch. XVI. 
be pleased with Chi's annexation, then Chi should go ahead and annex Yen; otherwise, it should not. ${ }^{61}$

Mencius warned the ruler of Chi: "The rest of the kingdom is already afraid of the strength of Chi; and now when with a doubled territory you do not put in practice a benevolent government; -it is this which sets the arms of others in motion." He thus advised the ruler of Chi to immediately order that all captives be restored, that the removal of precious vessels be stopped, that a new ruler of Yen be installed in consultation with its people, and that Chi withdraw as soon as the new ruler be in place. A humanitarian intervention must not end up in greater misery or, as Mencius put it, in "making the water more deep and the fire more fierce." 62

\section{Punitive Expeditions}

Punishment by the use of force may be inflicted upon a state for a serious violation of the rules of conduct by that state when commanded by the Son of Heaven or by the president of vassal states of a region. The very idea of commanding punishment signals correction by a higher authority against a subordinate. Therefore, the states, being co-equal, are not entitled to command correction among themselves. This explains the condemnation of all the wars during Spring and Autumn by Mencius since the belligerents were not entitled to punish each other ${ }^{63}$ When the king orders a punitive action, he entrusts its execution to the vassal states. "Thus the Son of Heaven commanded the punishment, but did not himself inflict it, while the heads of states inflicted the punishment, but did not command it." 64 When a head of a state acts to inflict a punishment pursuant to the order of the Son of Heaven, he is said to act as a "minister of Heaven." 65

A case of a punitive expedition was undertaken at the command of a regional president of vassal states. This occurred following the death of the ruler of the State Tsao while he participated in the joint invasion of Ch'in with Chin, Lu, et al. One of his sons, Fu-tsu, was

61. Works of Mencius, Bk. I, Pt. II, Ch. X.

62. Id., Bk. I, Pt. II, Ch. XI.

63. Id., Bk. VII, Pt. II, Ch. II. Mencius was especially critical of the five hegemons who "dragged the heads of states to punish other heads of states." He called them "sinners." The five were Hwan of Chi (684-642 B.C.), Wen of Chin (636-629), Moh of Ch'in (659-620), Hsiang of Sung (651-635), and King Chuang of Chu (613-591). Id., Bk. VI, Pt. II, Ch. VII.

64. Id.

65. Id., Bk. II, Pt. II, Ch. VIII. 
appointed by the people to take charge of the Tsao capital. Fu-tsu killed his eldest brother and made himself successor to the deceased ruler. This was a serious violation of $l i$. Immediately, the allies wanted to punish Fu-tsu. However, the leader of the allies, Chin decided to postpone this until the following year due to fatigue. The next year, Chin called a meeting of the states in order to undertake punitive action against Fu-tsu. Fu-tsu was invited and went to the meeting, apparently not suspecting anything. The ruler of Chin seized Fu-tsu and delivered him at the King's capital. ${ }^{66}$

In an earlier case in 711 B.C., three states, Chi, Lu and Cheng invaded the state of $\mathrm{Hsu}$ for a transgression of law. Their forces captured the capital of Hsu, and Hsu's ruler fled abroad. Upon the submission of $\mathrm{Hsu}$, the allied forces immediately ceased all military operations. Hsu was placed at the disposition of Cheng. Cheng's ruler made a high official of Hsu help the exiled ruler's younger brother rule, soothe and comfort the people. The ruler of Cheng told this Hsu official that in invading $\mathrm{Hsu}$, he merely acted as a tool of Heaven in punishing the guilty ruler of $\mathrm{Hsu}$. He did not consider himself an exemplary. ruler of his own household. He would not pretend to be worthy of ruling $\mathrm{Hsu}$, and his actions in $\mathrm{Hsu}$ were meant to serve the common interests of $\mathrm{Hsu}$ and Cheng. The ruler of Cheng's handling of Hsu was praised in the classics.

The above case is instructive on several points: (1) The invasion was undertaken for a specific limited purpose which was also a permissible purpose; (2) the actions of the allied powers were properly measured and commensurate with considerations of necessity and proportionality; (3) soothing and comforting the people of Hsu was foremost on the mind of the occupying power in charge; and (4) the actions of the ruler of Cheng were also commensurate with the quality of his own virtue. As remarked in the classics, "His arrangement of affairs was according to his measurement of his virtue ... his movements were according to the exigency of the times, so as not to burden those who should follow him." 67

A well-known case of unauthorized infliction of punishment because of lack of proper command involved the military actions by Chi against Yen. The ruler of Yen, Tzu-kuai resigned his throne to the prime

66. Note, Ch'un Ts'zw, at 388. For the case of a joint invasion of the guilty state of Ching by Chin, Lu and other states, See also Id., at 352.

67. Id., at 33. For the case of invasion of Cheng by Shih following "some strife of words." Shih was defeated, and its ruler was criticized partly for his failure to measure his own virtue against that of the ruler of Cheng, see id, at 33-34. 
minister, Tzu-chih, to duplicate the story of the sage king, Yao, who relinquished his throne to the sage Shun. ${ }^{63}$ Tzu-kuai did not expect Tzu-chih to accept the throne, but the latter surprised him. When Tzukuai's son took action to regain the throne, there was confusion and widespread suffering among the people. A high minister of Chi, Shen Tung, asked Mencius if Yen deserved punishment for this unauthorized gift and acceptance of the state between Tzu-kuai and Tzu-chih. Mencius replied positively. Whereupon, Chi smote Yen. When questioned if he had advised Chi's action, Mencius answered:

Shen Tung asked me whether Yen might be smitten, and I answered him, 'It may.' They accordingly went and smote it. If he had asked me, 'who may smite it?' I would have answered him, 'He who is the minister of Heaven may smite it. Suppose the case of a murderer, and that one asks me, 'May this man be put to death?' I will answer him, 'He may.' If he ask me, 'Who may put him to death?' I will answer him, 'The chief criminal judge may put him to death.' But now with one Yen [that is to say, Chi] to smite another Yen:-how should I have advised this? ${ }^{69}$

\section{The "Right" to Revolution}

Many have mentioned the "right to revolution" or "right to revolt" in Confucian thinking. ${ }^{70}$ It is probably more correct to say the "duty to bring about a revolution." Use of force in the discharge of that duty is not merely regarded as permissible but hailed by the Confucians. The two most celebrated cases are Tang of Shang os. Chich of Hsia and Wu of Chou vs. Chou of Shang. There are stringent requirements: (1) There must be an oppressive ruler who has repudiated the "decree of Heaven" by his abusive rule; (2) the revolt must be longed for by the oppressed people and is thus undertaken to carry out Heaven's sanctions against that ruler; and (3) the leader of the revolt must possess virtue commensurate with the righteous cause.

Chieh and Chou were two notorious despotic kings in Chinese history. Both Tang and $\mathrm{Wu}$, on the other hand, were among a small handful of the "sage kings." Tang, the ruler of the small principality

68. Works of Mencrus, Bk. V, Pt. I, Ch. V.

69. Id., Bk. II, Pt. II, Ch. VIII. It should be noted that following the events just mentioned, the people of Yen rose in rebellion against $\mathrm{Chi}$. Id., Bk. II, $\mathrm{Pt}$. II, Ch. IX.

70. See, e.g., Creel supra note 9, at 268-69. 
of Shang, rose against Chieh. Tang summarized Chieh's crimes: "The king of Hsia [Chieh] extinguished his virtue and played the tyrant, extending his oppression over you, the people of myriad regions."'1 And Tang explained his revolt:

The way of Heaven is to bless the good and to punish the bad. It sent down calamities on the House of Hsia, to make manifest its crimes. Therefore, I, the little child, charged with the decree of Heaven and its bright terrors, did not dare to forgive the criminal. ${ }^{22}$

The people of Hsia deplored their own plight: "When will this sun [i.e., King Chieh] expire? We will all perish with thee!" "73 It took Tang eleven expeditions to complete the revolution and Chieh was kept in banishment in Nan-tsao. It was reported that:

When Tang pursued his revolution in the east, the wild tribes of the west murmured, when he went in the south, those of the north murmured:- they said, 'Why does he make us alone the last?' To whatever people he went, they congratulated one another in their chambers, saying, "We have waited for our prince; he is come, and we revive."

At that time, people everywhere in Hsia "longed for Tang as if they longed for rain in a time of great drought."75

Wu of Chou recounted the crime of King Chou of Shang in great detail to the people:

[T] he king of Shang does not revere Heaven above, and inflicts calamities on the people below. He has been abandoned to drunkenness, and has been reckless in lust. He has dared to exercise cruel oppression. Along with criminals he punished all their relatives. He has put men into office on hereditary principle. He has made it his pursuit to have palaces, towers, pavilions, embankments, ponds, and all other extravagances, to the most painful injury of you, the myriad people. He has burned and wasted the loyal and good. He has ripped up pregnant women ... The iniquity of Shang is full. Heaven

71. The Book of Historical Documents, in The Chinese Classics, vol. III, Pt. IV, Bk. III, Ch. II. (J. Legge trans. 1960) (Hereafter Shoo KING).

72. Id., Pt. IV, Bk. III, Ch. II.

73. Id., Pt. IV, Bk. I, Ch. II.

74. Id., Pt. IV, Bk. II, Ch. IV; Works of Mencius, Bk. III, Pt. II, Ch. V.

75. Id. 
gives command to destroy it. If I did not comply with Heaven, my iniquity would be as great. ${ }^{76}$

So, Wu complied, succeeded in overthrowing Chou, the last king of Shang, and established the kingdom of Chou. As Wu pursued his revolutionary work, he too enjoyed overwhelming public support. In the words of Mencius:

Thus, the men of station of Shang took baskets full of black and yellow silks to meet the men of station of Chou, and the lower classes of the one met the other with baskets of rice and vessels of congee. Wu saved the people from the midst of fire and water, seizing only their oppressor and destroying him. ${ }^{77}$

In each of the above cases a subordinate revolted against his king. Years later, the king of Chi asked Mencius, "May a minister put his sovereign to death?" Mencius answered:

$\mathrm{He}$ - who outrages the benevolence proper to his nature, is called a robber; he who outrages righteousness, is called a ruffian. The robber and ruffian we call a mere fellow. I have heard the cutting off the the fellow Chou, but I have not heard of the putting a sovereign to death, in his case. ${ }^{78}$

In other words, when Chou abused the decree of Heaven by which he ruled, that decree became rescinded. Without the decree, Chou was reduced, in theory, to a mere "fellow." There was, therefore, no insubordination or disloyalty to speak of.

\section{Maximum Order}

The essence of the modern concept of "maximum order" is "greatest production and widest distribution of values." 79 The Confucian postulate of peaceful and happy world embraces a similar idea. In Confucius' portrait of the ideal state, he summarized it all by saying, "When the Great Way prevailed, the world community was equally shared by all."

76. Shoо King; Pt. V, Bk. I, Pt. i.

77. Works of Mencius, Bk. III, Pt. II, Ch. V.

78. Id., Bk. I, Pt. II, Ch. VIII.

79. For a definition of optimum order (equivalent of maximum order) see, e.g., M. S. McDougal, H. D. Lasswell and L. C. Chen, Human Rights and World Public Order 322-23 (1980).

80. See text at supra note 10. 
Values are preferred events. While the Confucians have never attempted to systematically categorize human preferences, they have touched upon all eight values as categorized by the policy scientists. ${ }^{81}$ The following is a tabular sampling:

Wealth "Riches and honors are what people desire." "H2 "Hence, the accumulation of wealth is the way to scatter the people; and the letting it be scattered among them is the way to collect the people."

Respect "Riches and honors are what men desire." "84 "[H]onor men of virtue and talents." 85

Power "The Record says, "If Confucius was three months without being employed by some ruler, he looked anxious and unhappy." "86 "The worthy and able were chosen as office-holders." 87

Enlightenment "Learn without satiety and teach without being tired." "In teaching there should be no distinction of classes." 89

Skill "By daily examinations and monthly trials, and by making their rations in accordance with their tasks:- this is the way to encourage the classes of artisans." 90

Well-Being "In the kingdom there are three things universally acknowledged to be honorable ... [A]ge is one of them." "The "The ancients caused the people to have pleasure as well as themselves, and therefore they could enjoy it." 92

Affection "Treat with reverence due to age the elders in your own family, so that the elders in the families of others shall be similarly treated; treat with kindness due to youth the young in your own family, so that the young in the families of others shall be similarly treated." 93

81. See McDougal, Lasswell and Reisman, supro note 32, at 201.

82. Confucian Analects, Bk. IV, Ch. V.

83. Great Learning, Commentary, Ch. $\mathbf{X}$.

84. Id.

85. Doctrine of the Mean, Ch. XX.

86. Works of Mencius, Bk. III, Pt. II, Ch. III.

87. See text at supra note 9.

88. Work OF Mencius, Bk. II, Pt. I, Ch. II.

89. Confucian Analects, Bk. XV, Ch. XXXVIII. What is taught can of course be related to either enlightenment or skill. Confucius himself taught theory and practice of virtue, speech (a diplomatic skill), theory and practice of government, and literary subjects including poetry, history, $l i$, and music. Id., Bk. XI, Ch. II; T. C. Chen, Theory of Confualus 292 et seq. (4th ed 1969) (In Chinese); S. S. Tsai, System of Confucian Thinking, Ch. viii, $\$ 5$ (1982) (In Chinese).

90. Doctrine of the Mean, Ch. XX.

91. Works of Mencius, Bk. II, Pt. II, Ch. II.

92. Id., Bk. I, Pt. I, Ch. II.

93. Id., Bk. I, Pt. I, Ch. VII. 
Rectitude "The superior man thinks of virtue." "What the Great Learning teaches, is-to illustrate illustrious virtue; to renovate the people; and to rest in the highest excellence." 95

The Confucians are concerned about the abundance of these values and they actively promoted policies that would encourage the promotion of skills of production, "96 "make the people rich," enable the greatest production of goods and services, ${ }^{98}$ provide widespread education through schools, ${ }^{99}$ inculcate filial and fraternal duties and other virtues, ${ }^{100}$ and so on. When they promoted the benevolent rule and the extension of the benefits of that rule to the people; the Confucians were naturally devoted to the goal of the greatest production of all values. As succinctly put by Mencius,

There is a way to get the kingdom:- get the people, and the kingdom is got. There is a way to get the people:-get their hearts, and the people are got. There is a way to get their hearts:-it is simply to collect for them what they want, and not to lay on them what they dislike. ${ }^{101}$

Confucius taught about benevolence. He said that "the benevolent man, wishing to be established himself [i.e., "self-perfection"], seeks -also to establish others [i.e., "perfection of others"]; wishing to be enlarged himself, he seeks also to enlarge others." 102 Confucius seems to think that sharing is more important than abundance. He said:

I had heard that rulers of states and chiefs of families are not troubled as much with fears of poverty as with failures to attain equal and fair distribution. . . For when there is equal and fair distribution, there will be no poverty. ${ }^{103}$

In inter-state relations, there were many specific cases of state practices that may be regarded as either compatible or incompatible with maximum order. In 716 B.C., for example, a high minister presented a remonstrance to the ruler of Chen. Chen's ruler refused

94. Confucian Analects, Bk. IV, Ch XI.

95. Great Learning, Text of Confucious, 1.

96. Doctrine of the Mean, Ch. XX.

97. Works of Mencius, Bk. VII, Pt. I, Ch. XXIII.

98. Id., Bk. I, Pt. I, Ch. III; Great learning, Ch. X.

99. Works of Mencius, Bk. I, Pt. I, Ch. III.

100. Id.

101. Id., Bk. IV, Pt. I, Ch. IX.

102. Confucian Analects, Bk. VI, Ch. XXVIII.

103. Id., Bk. XVI, Ch. I. 
to accept an offer to conclude peace from the ruler of Cheng who had invaded Chen the year before. "Intimacy with the virtuous and friendship with its neighbors are the jewels of a State." 104 In 549 B.C. the ruler of Chin was criticized for violation of $l i$ when he failed to discontinue his usual enjoyment of music on the death of the ruler of a neighboring state, Chee. ${ }^{105}$ According to $l i$, a state must cease all impending military operations against another state on the death of the latter's ruler. Shih-kai of Chin was said to know $l i$ when he ceased making an incursion into Chi in 553 B.C. upon hearing of the death of the ruler of the latter state. ${ }^{106}$ On the other hand both Cheng and Wei violated $l i$ because each invaded the other on the death of the invaded state's ruler. Wei's invasion was also disparagingly characterized as "recompensing injury for injury." "107

The way Confucius recorded in Spring and Autumn the battle of Han (644 B.C.) between Chin and Ch'in was said to imply his censure of the ruler of Chin's handling of his relations with the ruler of Ch'in. Tso's Commentary, in providing details, noted facts that apparently contrasted the more virtuous conduct of the shrewd ruler of $\mathrm{Ch}^{\prime}$ in. $\mathrm{Ch}$ 'in had been forthcoming to the ruler of Chin in times of need, including helping him to enter and get the state and sharing its grain with Chin during scarcity. The faithless and ungrateful ruler of Chin not only broke all his promises to $\mathrm{Ch}^{\prime}$ in but also refused to allow the sale of grain to Ch'in when scarcity became Ch'in's lot. Ch'in won the battle of $\mathrm{Han}$ and took the ruler of Chin prisoner. After detaining Chin's ruler for a while, Ch'in released him. Tso's Commentary reported a view on the wisdom of releasing this prisoner which appealed to the ruler of $\mathrm{Ch}^{\prime}$ in:

To take him prisoner because of his duplicity, and to let him go on his real submission:- what virtue could be greater than this? what punishment more awing? Those who submit to Ch'in will cherish the virtue; those who are disaffected will dread the punishment:-the presidency of $\mathrm{Ch}^{\prime}$ in over the States may be secured by its conduct in this case. . . that same year, Chin had again a scarcity, and the earl of Ch'in

104. Ch'un Ts'ew, at 21.

105. Id., at 500 .

106. Id., at 483 .

107. Id., at 416. See also Tsang Liu's commentary on the events under Duke Hsiang, Year II, 5, which appears in most Chinese editions of THE Five CHING readers; compare Confucian Analegts, Bk. XIV, Ch. XXXV. 
again supplied it with grain, saying, 'I feel angry with its ruler, but I pity its people.' ${ }^{108}$

There were also instances of inter-state agreements aimed ostensibly at promoting maximum order. The more notable multilateral ones included the agreement concluded in connection with the famous " $\mathrm{Cov}$ enant of Kwei-chew" of 650 B.C. and the agreement concluded in 561 B.C. between twelve states. The first was concluded under the hegemony of Chi but in the presence of the prime minister of the king of Eastern Chou; the latter, under the hegemony of Chin.

Mencius criticized the rulers of his time as "sinners" for their disregard of the principles contained in the Kwei-chew agreement. He narrated these injunctions:

The first injunction in their agreement was, - 'Slay the unfilial; change not the son who has been appointed heir; exalt not a concubine to be the wife.' The second was,- 'Honor the worthy, and maintain the talented, to give distinction to the virtuous.' The third was, - 'Respect the old, and be kind to the young. Be not forgetful of strangers and travellers.' The fourth was, - 'Let not offices be hereditary, nor let officers be pluralists. In the selection of officers let the object be, to get the proper men. Let not a ruler take it on himself to put to death a great officer.' The fifth was,- 'Follow no crooked policy in making embankments. Impose no restrictions on the sale of grain. Let there be no promotions without first announcing them to the sovereign.' It was then said, 'All we who have united in this agreement shall hereafter maintain amicable relations.' ${ }^{109}$

The words of the covenant of 561 B.C. were recorded in Tso's Commentary:

All we who covenant together agree not to hoard up the produce of good years, not to shut one another out from advantages [that we possess], not to protect traitors, not to shelter criminals. We agree to aid one another in disasters and calamities, to have compassion towards one another in seasons of misfortune and disorder, to cherish the same likings and dislikings, to support and encourage the royal House. Should any prince break these engagements, may $\mathrm{He}$ who watches over men's sincerity and He who watches over cov-

108. Ch'UN Ts'EW, at 167-69.

109. Works of Mencius, Bk. VI, Pt. II, Ch. VII. 
enants ... destroy him, so that he shall lose his people, his appointment pass from him, his family perish, and his State be utterly overthrown. ${ }^{110}$

\section{Conclusion}

Light shineth by whatever name it may be called, religion or another. In the pursuit of world order, one view will illuminate the path as far as it will go: but when many and different views are looked at in relation to one another, they will together illuminate a much brighter path. 
